\title{
Efektivitas Metode Discovery dan Media Youtube Terhadap Siswa Kelas V SD N Tlahap Dalam Materi Fotosintesis
}

\author{
Bargi \\ Guru SD Negeri Tlahap, Kec. Kledung, Kab. Temanggung \\ *Coresponding author: bargi@gmail.com
}

\section{A R T I CLE INFO}

Article history:

Received: Mei 2019

Accepted: September 2019

\section{Keywords:}

Efektivitas, discovery, youtube, fotosintesis

\begin{abstract}
ABSTRAK
Pembelajaran di Sekolah Dasar akan lebih efektif, menarik, dan menyenangkan apabila guru dalam menjelaskan materi pelajaran memanfaatkan berbagai media dan metode secara bervariasi. Penggunaan metode yang tidak bervariasi, menjadikan hasil belajar sangat rendah seperti yang terjadi pada siswa kelas V SDN Tlahap tahun pelajaran 2018/2019. Untuk memecahkan masalah tersebut, peneliti melakukan tindakan dengan mengubah metode dan media pembelajaran, yang semula menggunakan mengunakan metode konvensional diganti metode discovery dan media youtube. Tujuan dari penelitian ini adalah untuk meningkatkan minat dan motivasi belajar pada siswa kelas V SDN Tlahap tahun pelajaran 2018/2019 pada materi fotosintesis yang nilainya masih rendah. Dalam menggunakan metode discovery dan media youtube siswa diajak untuk mengamati dari video yang diambil dari youtube kemudian diarahkan untuk berdiskusi dalam kelompok. Hasil diskusi disampaikan di depan kelas dan ditanggapi oleh kelompok lain, yang kemudian akan disimpulkan bersama guru. Sumber data diambil dari pretest sebelum dilakukan tindakan untuk mengetahui kemampuan awal, dan postest pada akhir siklus kedua. Dalam tiap siklus, penggunaan metode discovery dan media youtube meningkatkan hasil belajar karena lebih menarik, menyenangkan, dan pengetahuannya pun diperoleh dari pengalaman belajar sendiri bersama teman-temannya. Hasil belajar terbukti lebih baik ada peningkatan sebesar $60,87 \%$
\end{abstract}

\section{PENDAHULUAN}

Pembelajaran di Sekolah Dasar akan lebih efektif, menarik, dan menyenangkan apabila guru dalam menjelaskan materi pelajaran memanfaatkan berbagai media dan metode secara bervariasi. Pembelajaran yang bervariasi bertujuan agar menimbulkan minat dan motivasi belajar siswa terhadap semua mata pelajaran di sekolah. Dengan motivasi 
belajar yang tinggi, maka hasil belajar akan berkualitas sehingga mutu pendidikan akan meningkat. Namun kenyataan di lapangan menunjukkan bahwa kegiatan pembelajaran di Sekolah Dasar masih jauh dari harapan, berdasarkan pengamatan dan informasi dari berbagai pihak masih banyak yang bersifat konvensional dan banyak ceramah, sehingga pembelajaran di sekolah dasar membosankan.

Pembelajaran yang kurang menarik akan membosankan siswa dan motivasi belajar kurang. Apalagi dalam pembelajaran IPA materi fotosintesis, hampir semua siswa masih berangan angan memahami tumbuhan yang telah memasak makanannya sendiri, dan menganggap materi fotosintesis sebagai materi pelajaran yang sulit dipahami. Kurang dipahaminya materi pelajaran oleh siswa, mengakibatkan hasil belajar tidak maksimal. Tidak maksimalnya hasil belajar, terbukti dalam kegiatan pembelajaran yang dilakukan di kelas V SD Negeri Tlahap, Kecamatan Kledung, Kabupaten Temanggung semester 1 tahun pelajaran 2018/2019, yang jumlah siswa ada 23 dengan latar belakang yang tidak sama. Pembelajaran semula hanya dengan metode ceramah dalam materi fotosistesis, ternyata hasil belajar siswa yang mencapai Kriteria Ketuntasan Minimal (KKM) yang ditentukan sekolah yaitu 70, hanya 8 siswa (34,78\%) dari jumlah siswa sebanyak 23 siswa. Sedangkan 15 siswa $(65,21 \%)$ tidak mencapai KKM yang telah ditentukan.

Dari data di atas, ternyata masalah dapat teridentifikasi dari metode yang digunakan oleh guru masih menggunakan metode konvensional, dan tidak menggunakan media pembelajaran. Sehingga, peneliti sekaligus guru kelas mendapatkan masukan dan informasi dari berbagai pihak untuk menentukan model pembelajaran baru agar motivasi dan hasil belajar siswa dalam pembelajaran IPA materi fotosintesis dapat meningkat. Media yang dipilih adalah media youtube fotosintesis dan metode discovery. Dipilihnya media youtube fotosintesis dan metode discovery karena berdasarkan pengamatan peneliti, siswa lebih antusias dan tertarik ketika pelajaran menggunakan media komputer atau proyektor. Sehingga materi pelajaran fotosintesis didesain dengan menggunakan youtube dengan tujuan untuk menarik motivasi belajar siswa. Pembelajaran dengan media youtube dan metode discovery ini dipilih oleh guru kelas untuk mengatasi permasalahan yang dihadapi siswa. Pembelajaran dengan memanfaatkan media youtube dan metode discovery ini agar dapat meningkatkan motivasi dan hasil belajar IPA materi fotosintesis bagi siswa kelas V SDN Tlahap Kec. Kledung Kab. Temanggung. Hasil belajar siswa setelah mengikuti kegiatan pembelajaran ini diharapkan mencapai KKM yang ditentukan yaitu 70, serta rata-rata kelas yang dicapai meningkat dari hasil sebelumnya.

Berdasarkan deskripsi dalam latar belakang masalah di atas maka peneliti merumuskan permasalahan sebagai berikut: "Apakah metode discovery dan media youtube dapat meningkatkan motivasi dan hasil belajar siswa materi fotosintesis pada siswa kelas V SD Negeri Tlahap Kec. Kledung Kab Temanggung tahun pelajaran 2018/2019?"

Adapun penelitian ini bertujuan untuk: 1) mendeskripsikan penggunaan metode discovery dan media youtube fotosintesis dapat meningkatkan hasil belajar siswa materi fotosinsesis pada siswa kelas V SD Negeri Tlahap Kec. Kledung Kab Temanggung tahun pelajaran 2018/2019. 2) menganalisis efektifitas penggunaan metode discovery dan media youtube dalam upaya meningkatkan motivasi dan hasil belajar siswa materi fotosintesis siswa kelas V SD Negeri Tlahap Kec. Kledung Kab Temanggung tahun pelajaran 2018/2019.

Penelitian ini diharapkan akan memberikan manfaat kepada beberapa pihak, antara lain: 1) diharapkan memberikan pengalaman baru bagi siswa untuk senantiasa belajar dan dapat memanfaatkan sarana teknologi yang telah ada sehingga sisswa tidak gagap teknologi (gaptek) dan prestasi belajar mata pelajaran IPA meningkat, 2) diharapkan dapat memberikan motivasi pada semua guru, khususnya guru sekolah dasar untuk dapat menggunakan media youtube atau tekhnologi lainnya, guna meningkatkan hasil belajar 
siswa dalam setiap mata pelajaran, 3) diharapkan dapat menambah wawasan baru tentang media dan metode pembelajaran yang digunakan guru dalam proses pembelajaran di Sekolah Dasar khususnya dan dunia pendidikan pada umumnya.

\section{Efektifitas}

Menurut Bungkaes (2013), efektifitas adalah hubungan antara output dan tujuan. Dalam artian efektifitas merupakan ukuran seberapa jauh tingkat output, kebijakan dan prosedur dari organisasi mencapai tujuan yang ditetapkan. Dalam pengertian teoritis atau praktis, tidak ada persetujuan yang universal mengenai apa yang dimaksud dengan "Efektifitas". Bagaimanapun definisi efektifitas berkaitan dengan pendekatan umum. Bila ditelusuri efektifitas berasal dari kata dasar efektif yang artinya : (1). Ada efeknya (pengaruhnya, akibatnya, kesannya) seperti: manjur; mujarab; mempan; (2). Penggunaan metode/cara, sarana/alat dalam melaksanakan aktivitas sehingga berhasil guna (mencapai hasil yang optimal).

Budiani (2009) mengutip pendapat Subagyo bahwa efektifitas adalah kesesuaian antara output dengan tujuan yang ditetapkan. Efektifitas adalah suatu keadaan yang terjadi karena dikehendaki. Menurut Richard Steer, efektifitas harus dinilai atas dasar tujuan yang bisa dilaksanakan, bukan atas dasar konsep tujuan yang maksimum.

Efektifitas diukur dengan menggunakan standar sesuai dengan acuan Litbang Depdagri dalam Budiani (2009) seperti pada tabel dibawah

\begin{tabular}{cc}
\hline Rasio Efektifitas & Tingkat Capaian \\
\hline Dibawah 40 & Sangat Tidak Efektif \\
$40-59,99$ & Tidak Efektif \\
$60-79,99$ & Cukup Efektif \\
Di atas 80 & Sangat Efektif \\
\hline
\end{tabular}

Dari penjelasan di atas, peneliti menyimpulkan bahwa efektifitas yang dimaksud dalam penelitian ini adalah suatu keadaan yang ingin di kehendaki sesuai dengan tujuan awal, seperti hubungan sebab akibat yang kemudian digunakan untuk mengukur hasil belajar siswa dalam bentuk nilai.

\section{Hakekat Belajar}

Menurut Sudjana (2001:28), mendefinisikan belajar merupakan suatu proses yang ditandai dengan adanya perubahan pada diri seseorang. Sedang (Gie, 1980) menyatakan bahwa belajar adalah segenap rangkaian atau aktivitas yang dilakukan secara sadar oleh seseorang dan mengakibatkan perubahan dirinya, berupa perubahan atau kemahiran yang sifatnya sedikit banyak permanen.

Berdasarkan beberapa pendapat di atas maka peneliti menyimpulkan bahwa, belajar adalah suatu kegiatan yang dapat menghasilkan perubahan tingkah laku, baik potensial maupun aktual. Belajar merupakan aktivitas yang dilakukan oleh seseorang untuk memperoleh perubahan tingkah laku.

\section{Motivasi Belajar Siswa}

Ada beberapa faktor yang dapat mempengaruhi belajar siswa . (Suryabrata, 1998) mengemukakan faktor-faktor itu sebagai berikut:

\section{a. Faktor dari Intern}

Faktor intern adalah faktor dari dalam yaitu faktor-faktor yang dapat mempengaruhi belajar yang berasal dari siswa yang sedang belajar. Faktor-faktor ini meliputi:

1. Fisiologi, meliputi kondisi jasmaniah secara umum dan kondisi panca indra. Anak 
yang segar jasmaninya akan lebih mudah proses belajarnya. Anak -anak yang kekurangan gizi ternyata kemampuan belajarnya di bawah anak-anak yang tidak kekurangan gizi, kondisi panca indra yang baik akan memudahkan anak dalam proses belajar.

2. Kondisi psikologis, yaitu beberapa faktor psikologis utama yang dapat mempengaruhi proses dan hasil belajar adalah kecerdasan, bakat minat, motivasi, emosi dan kemampuan kognitif. Adapun penjabaran dari faktor tersebut adalah:

a) Faktor kecerdasan yang dibawa individu mempengaruhi belajar siswa. Semakin individu itu mempunyai tingkat kecerdasan tinggi, maka belajar yang dilakukannya akan semakin mudah dan cepat sebaliknya semakin individu itu memiliki tingkat kecerdasan rendah, maka belajarnya akan lambat dan mengalami kesulitan belajar;

b) Bakat individu satu dangan lainnya tidak sama, sehingga menimbulkan belajarnyapun berbeda. Bakat merupakan kemampuan awal anak yang dibawa sejak lahir;

c) Minat individu merupakan ketertarikan individu terhadap sesuatu. Minat belajar siswa yang tinggi menyebabkan belajar siswa lebih mudah dan cepat;

d) Motivasi belajar antara siswa yang satu dengan siswa lainnya tidaklah sama. Adapun pengertian motivasi belajar itu menurut (Tim MKDK, 1996: 46) adalah "Sesuatu yang menyebabkan kegiatan belajar terwujud". Motivasi belajar dipengaruhi oleh beberapa faktor, antara lain: cita-cita siswa, kemampuan belajar siswa, kondisi siswa, kondisi lingkungan, unsur-unsur dinamis dalam belajar dan upaya guru membelajarkan siswa. (Tim MKDK, 1996: 50-51);

e) Emosi merupakan kondisi psikologi (jiwa) individu untuk melakukan kegiatan, dalam hal ini adalah untuk belajar. Kondisi psikologis siswa yang mempengaruhi belajar antara lain: perasaan senang, kemarahan, kejengkelan, kecemasan dan lain-lain;

f) Kemampuan kognitif siswa yang mempengaruhi belajar mulai dari aspek pengamatan, perhatian, ingatan, dan daya pikir siswa.

\section{b. Faktor Ekstern}

Faktor ekstern adalah faktor dari luar yaitu faktor-faktor yang berasal dari luar siswa yang mempengaruhi proses dan hasil belajar. Faktor-faktor ini meliputi:

1) Keadaan udara mempengaruhi proses belajar siswa. Apabila udara terlalu lembab atau kering kurang membantu siswa dalam belajar. Keadaan udara yang cukup nyaman dilingkungan belajar siswa akan membantu siswa untuk belajar dengan lebih baik;

2) Waktu belajar mempengaruhi proses belajar siswa misalnya: pembagian waktu siswa untuk belajar dalam satu hari;

3) Cuaca yang terang benderang dengan cuaca yang mendung akan berbeda bagi siswa untuk belajar. Cuaca yang nyaman bagi siswa membantu siswa untuk lebih nyaman dalam belajar;

4) Tempat atau gedung sekolah mempengaruhi belajar siswa. Gedung sekolah yanng efektif untuk belajar memiliki ciri-ciri sebagai berikut: letaknya jauh dari tempat-tempat keramaian (pasar, gedung bioskop, bar, pabrik dan lain-lain), tidak menghadap ke jalan raya, tidak dekat dengan sungai, dan sebagainya yang membahayakan keselamatan siswa;

5) Alat-alat pelajaran yang digunakan baik itu perangkat yang lunak (seperti transparan) ataupun perkakas yang keras (misalnya OHP).

Dengan deskripsi di atas, dapat diketahui bahwa motivasi belajar merupakan faktor internal yang mempengaruhi hasil belajar siswa . Kaitannya dengan penelitian ini 
dimanfaatkannya media youtube fotosintesis dan metode discovery merupakan upaya untuk meningkatkan motivasi belajar dan hasil belajar siswa dalam pembelajaran IPA kelas V SDN Tlahap materi fotosintesis.

\section{Metode Pembelajaran}

Metode secara harfiah berarti cara atau strategi. Metode adalah cara yang telah diatur dan terpikir untuk mencapai tujuan. Simanjutak (1983:13) menyatakan bahwa metode adalah cara yang sistematis yang digunakan untuk mencapai tujuan. Metode mengajar merupakan salah satu cara yang dipergunakan guru dalam mengadakan hubungan dengan sesuatu pada saat berlangsungnya pembelajaran (Suryosubroto, 1997: 43)

Setiap metode memiliki kelebihan dan kekurangan. Kekurangan dari suatu metode dapat ditutupi oleh metode lainnya. Oleh karena itu tidak ada metode mengajar yang paling baik. Dengan demikian guru tidak hanya menggunakan satu metode dalam proses mengajarnya, tetapi dapat menggunakan beberapa metode.

Metode yang dipilih dalam penelitian ini adalah metode discovery. Karena menurut (Herdian, 2010) metode discovery : (1) merupakan suatu cara untuk mengembangkan cara belajar siswa aktif; (2) dengan menemukan dan menyelidiki sendiri konsep yang dipelajari, maka hasil yang diperoleh akan tahan lama dalam ingatan dan tidak mudah dilupakan siswa; (3) pengertian yang ditemukan sendiri merupakan pengertian yang betul-betul dikuasai dan mudah digunakan atau ditransfer dalam situasi lain; (4) dengan menggunakan strategi discovery anak belajar menguasai salah satu metode ilmiah yang akan dapat dikembangkan sendiri; (5) siswa belajar berpikir analisis dan mencoba memecahkan problema yang dihadapi sendiri, kebiasaan ini akan ditransfer dalam kehidupan nyata.

Menurut Hosnan (2014:282), discovery learning adalah suatu model untuk mengembangkan cara belajar aktif dengan menemukan sendiri, menyelidiki sendiri, maka hasil yang diperoleh akan setia dan tahan lama dalam ingatan. Melalui belajar penemuan, siswa juga bisa belajar berpikir analisis dan mencoba memecahkan sendiri masalah yang dihadapi.

Menurut Kurniasih, dkk (2014:64), Model discovery learning adalah proses pembelajaran yang terjadi bila pelajaran tidak disajikan dengan pelajaran dalam bentuk finalnya,tetapi diharapkan siswa mengorganisasikan sendiri. Discovery adalah menemukan konsep melalui serangkaian data atau informasi yang diperoleh melalui pengamatan atau percobaan (Toy, et al., 2018; Bahtiar, \& Dukomalamo, 2019)).

Beberapa keunggulan metode penemuan juga diungkapkan oleh Suherman, dkk (2001: 179) sebagai berikut:

1. Siswa aktif dalam kegiatan belajar, sebab ia berpikir dan menggunakan kemampuan untuk menemukan hasil akhir;

2. Siswa memahami benar bahan pelajaran, sebab mengalami sendiri proses menemukannya. Sesuatu yang diperoleh dengan cara ini lebih lama diingat;

3. Menemukan sendiri menimbulkan rasa puas. Kepuasan batin ini mendorong ingin melakukan penemuan lagi sehingga minat belajarnya meningkat;

4. Siswa yang memperoleh pengetahuan dengan metode penemuan akan lebih mampu mentransfer pengetahuannya ke berbagai konteks;

5. Metode ini melatih siswa untuk lebih banyak belajar sendiri.

\section{Media Pembelajaran}

Djamarah (2006:120) menjelaskan bahwa kata media berasal dari bahasa latin yang merupakan bentuk jamak dari kata "medium", yang secara harfiah bararti perantara atau pengantar. Dengan demikian, media merupakan wahana penyalur informasi belajar atau 
penyalur besar. Bila media adalah sumber belajar, maka secara luas media dapat diartikan dengan manusia, benda, maupun peristiwa yang menyingkirkan anak didik memperoleh pengetahuan dan keterampilan

Media yang digunakan dalam pembelajaran ada bermacam-macam, mulai dari media yang sederhana hingga media yang rumit dan modern. Media pengajaran merupakan alat bantu dalam mengajar. Media pengajaran dapat mempertinggi proses belajar siswa dalam pengajaran yang akan menyebabkan hasil belajar yang tinggi pula.

Menurut Simamora (2009), fungsi media pembelajaran adalah :

1. Memperjelas pesan pembelajaran agar tidak terlalu verbalistis

2. Mengatasi keterbatasan ruang, waktu, tenagadan panca indra

3. Menimbulkan semangat belajar, interaksi langsung antara siswa dengan sumber belajar

4. Memungkinkan siswa belajar mandiri sesuai dengan kemampuan visual, auditori serta kinestetiknya

5. Memberi stimulus yang sama, membandingkan pengalaman dan menimbulkan persepsi yang sama

Dalam penelitian ini, media yang digunakan dalam menjelaskan materi fotosintesis, peneliti menggunakan media pembelajaran yang dapat digunakan pada program pendidikan, salah satunya adalah dengan menggunakan tekhnologi komputer dan internet sebagai penunjang kegiatan belajar mengajar. Penggunaan media ini memberikan beberapa keuntungan diantaranya dapat diakses kapanpun dan dimanapun. Salah satu media penunjang pembelajaran berbasis internet yang dapat memvisualisasikan tekhnik dan materi pembelajaran dengan baik adalah youtube.

Youtube adalah layanan video sharing populer dimana para penggunanya dapat memuat, menonton dan berbagi klip video secara gratis. YouTube menjadi salah satu media sosial yang praktis dan mudah diakses. Media sosial menjadi alat pengajaran penting untuk menyebarkan informasi kepada siswa, pasien dan keluarganya. Penggunaan video interaktif seperti YouTube ke dalam proses pembelajaran akan meningkatkan pemahaman dan penguasaan ketrampilan siswa (Burnett, Melissa, 2008).

\section{Hasil belajar Siswa}

Untuk mengetahui hasil belajar siswa perlu adanya evaluasi sebagai alat untuk mengukur hasil belajar. Pemberian nilai menurut Arikunto (1997:274) merupakan suatu pekerjaan yang memberikan suatu feed back (umpan balik) yang mencerminkan seberapa jauh seorang siswa telah mencapai tujuan yang ditetapkan dalam tujuan pembelajaran.

Hasil belajar yang dimaksudkan dalam penelitian ini adalah hasil belajar siswa dalam mata pelajaran IPA khususnya untuk kelas V semester 1 tahun pelajaran 2018/2019 pada materi fotosintesis. Hasil belajar ini diperoleh siswa setelah siswa mengikuti kegiatan pembelajaran yang dilakukan guru dengan memanfaatkan media youtube dalam upaya meningkatkan motivasi belajar dan pemahaman siswa.

\section{Fotosintesis}

Fotosintesis berasal dari kata foton yang berarti cahaya dan sintesis yang berarti penyusunan. Jadi fotosintesis adalah proses penyusunan dari zat organik $\mathrm{H} 2 \mathrm{O}$ dan $\mathrm{CO} 2$ menjadi senyawa organik yang kompleks yang memerlukan cahaya. Fotosintesis hanya dapat terjadi pada tumbuhan yang mempunyai klorofil, yaitu pigmen yang berfungsi sebagai penangkap energi cahaya matahari (Kimball, 2002: 179).

Fotosintesis menyediakan makanan bagi hampir seluruh kehidupan dunia baik secara langsung ataupun tak langsung. Organisme memperoleh senyawa organik yang digunakannya untuk energi dan rangka karbon dengan satu atau dua cara utama : nutrisi autotrofik atau heterotrofik. Tumbuhan disebut autotrof karena nutrien satu-satunya yang mereka butuhkan adalah karbondioksida dari udara dan air serta mineral dari tanah. 
Secara khusus, tumbuhan merupakan fotoautotrof yaitu organisme yang menggunakan cahaya sebagai sumber energi untuk mensintesis lipid, protein dan bahan organik lainnya. Fotosintesis juga terjadi dalam algae termasuk protista tertentu, dan dalam sebagian prokariota (Campbell, 2002:181).

Fotosintesis terjadi pada semua bagian tumbuhan yang berwarna hijau. Sebagian besar zat warna hijau daun atau klorofil terdapat pada daun sehingga merupakan organ utama untuk fotosintesis. Dalam struktur daun, mesofil adalah jaringan dasar yang terletak antara epidermis atas dan epidermis bawah. Untuk tumbuhan dikotil, mesofilnya berkembang menjadi jaringan tiang dan jaringan bunga karang. Fotosintesis terjadi terutama pada jaringan tiang dan bunga karang. Kandungan klorofil pada jaringan tiang lebih banyak daripada jaringan spons.

Fotosintesis bukanlah reaksi tunggal, melainkan terdiri dari beberapa tahap reaksi yang kompleks. Adapun proses fotosintesis pada tumbuhan dapat dijelaskan sebagai berikut: 1) Reaksi terang (reaksi yang berlangsung dengan cahaya) (a) Sinar matahari ditangkap oleh klorofil, diserap oleh akar dari dalam tanah, oleh pembuluh xilem air diangkut kedaun. (b) Klorofil menyerap cahaya merah, energi yang ditangkap oleh klorofil digunakan untuk memecah molekul air. Pemecahan ini disebut sebagai fotolisis. 2) Reaksi gelap (reaksi yang berlangsung tanpa cahaya) yaitu : (a) Terjadi proses pengikatan karbon dioksida didalam daun (b) Karbon dioksida ini akan bergabung dengan ion hidrogen yang dihasilkan oleh reaksi terang, membentuk glukosa (gula).

Hasil akhir fotosintesis berupa : (1) Hasil akhir fotosintesis adalah gula sederhana beratom C-3, kemudian diubah menjadi gula, misalnya glukosa. (2) Glukosa diangkut melalui floem ke sel-sel daun yang lain yang tidak berfotosintesis, sel-sel batang, dan selsel akar untuk keperluan tumbuhan itu sendiri. Sisanya akan diubah kedalam bentuk lain yaitu menjadi amilum, protein dan lipid yang disimpan untuk cadangan makanan. (3) Hasil lain dari fotosintesis adalah oksigen. Oksigen akan dilepas kelingkungan melalui stomta. Oksigen yang dilepas dimanfaatkan oleh makhluk hidup untuk proses respirasi.

Dari penjelasan di atas, peneliti menyimpulkan bahwa fotosintesis adalah proses penyusunan dari $\mathrm{CO}_{2}$, mineral dan $\mathrm{H}_{2} \mathrm{O}$ yang dibantu oleh pigmen klorofil untuk menangkap energi cahaya matahari, yang digunakan untuk memenuhi nutrisi yang dibutuhkan oleh tumbuhan. Dalam menyampaikan materi fotosintesis di kelas V sekolah dasar, tidak sedikit dari siswa yang kesulitan dalam memahami proses fotosintesis yang terjadi pada tumbuhan, ditambah guru waktu menyampaikan materi hanya mengandalkan metode ceramah. Oleh karena itu, dalam meningkatkan pemahaman siswa yang berdampak pada hasil belajar, guru sebagai peneliti menggunakan media youtube dengan harapan pemahaman terhadap materi dapat meningkat, dan hasil belajarnyapun juga baik. Peneliti menganggap dengan video dari youtube, siswa akan mendapatkan pengalaman secara langsung dari melihat proses fotosintesis, apalagi ditambah dengan metode yang digunakan adalah metode discovery yang nantinya siswa akan menemukan sendiri konsep pengetahuan proses fotosintesis dalam tumbuhan hijau.

\section{Kerangka Berpikir}

Peneliti melaksanakan kegiatan pembelajaran dengan menggunakan media youtube dengan metode discovery dalam setiap tahapan, sehingga dapat meningkatkan pemahaman siswa yang berdampak pada hasil belajar karena siswa dapat secara aktif belajar dan berdiskusi sekaligus menemukan konsep pemahaman materi belajar sendiri bersama teman-temannya. Sehingga peneliti optimis hasil belajar IPA materi fotosintesis pada siswa kelas V SD Negeri Tlahap dapat meningkat setelah dilakukan evaluasi (Ulangan, Tugas Mandiri, PR) dalam pelaksanaan pembelajaran dengan menggunakan metode discovery dan media youtube. 


\section{Hipotesis}

Hipotesis merupakan suatu pernyataan yang penting dalam penelitian, yang memberikan pedoman dan pengarahan pada penelitian serta dalam pemecahan masalah. Sutrisno (1997:63), menyatakan bahwa hipotesis adalah dugaan yang mungkin benar atau juga mungkin salah atau bahkan palsu dan diterima apabila dari hipotesis tersebut dapat dibenarkan atau dapat dibuktikan kebenarannya atau fakta-fakta yang membenarkan.

Berdasarkan landasan teori di atas peneliti merumuskan hipotesis yang diajukan dalam penelitian ini adalah: "Penggunaan metode discovery dan media youtube fotosintesis dapat meningkatkan motivasi dan hasil belajar siswa dalam pembelajaran IPA materi fotosintesis bagi siswa kelas V SD Negeri Tlahap Kec. Kledung Kab. Temanggung tahun pelajaran 2018/2019”.

\section{METODE PENELITIAN \\ Setting Penelitian}

Penelitian ini dilaksanakan pada semester 1 tahun pelajaran 2018/2019. Masingmasing siklus dilakukan kegiatan pembelajaran sebanyak dua kali pertemuan. Tindakan diberikan pada waktu jam pelajaran IPA, sesuai dengan jadwal pelajaran, yang dilaksanakan setiap hari Senin dan Rabu. Kegiatan ini dilaksanakan sesuai dengan program semester 1 yang telah direncanakan oleh guru kelas berdasarkan kurikulum KTSP yang digunakan di SD Negeri Tlahap.

\section{Subjek dan Tempat Penelitian}

Subjek penelitian tindakan kelas ini adalah siswa kelas V SD Negeri Tlahap Kecamatan Kledung Kabupaten Temanggung semester I tahun pelajaran 2018/2019. berjumlah 23 siswa, terdiri dari 15 siswa laki-laki dan 8 siswa perempuan. Penelitian dilaksanakan di kelas V SD Negeri Tlahap Kec. Kledung Kab. Temanggung.

\section{Sumber Data}

Sumber data dari penelitian ini diperoleh dari: (1) Daftar nilai, 2) Perangkat pembelajaran yang dibuat peneliti, (3) Buku sumber pelajaran, dan (4) Hasil observasi, saran dari observer yang dilakukan sebelum, selama, dan sesudah tindakan penelitian, dan 5) dokumentasi selama tindakan diberikan.

\section{Teknik dan Alat Pengumpulan Data}

Teknik yang digunakan untuk mengumpulkan data berbentuk tes dan observasi. Tes digunakan untuk mengetahui peningkatan hasil belajar siswa selama kegiatan pembelajaran IPA materi fotosintesis. Lembar observasi digunakan untuk menilai keaktifan dan perubahan tingkah laku siswa yang berkaitan erat dengan motivasi belajar dalam pembelajaran IPA selama kegiatan dilakukan.

Alat pengumpulan data tergantung pada teknik yang digunakan. Teknik tes, alatnya dapat berbentuk butir soal tes. Butir soal tes ini berupa tes isian singkat yang terdiri atas 10 soal. Teknik non tes, alatnya dapat berbentuk pedoman dan lembar observasi.

\section{Validasi Data}

Dari sejumlah instrumen yang digunakan harus memiliki validitas yang handal. Menurut Suharsimi (1987:136) yang dimaksud dengan validitas adalah "suatu ukuran yang menunjukkan tingkat-tingkat kevalitan atau kesahihan sesuatu instrumen.

Dalam penelitian ini menggunakan validitas teman sejawat, yakni teman sejawat yang menganalisis dan mengoreksi soal-soal yang telah disusun peneliti sebelum digunakan dalam penelitian. Adapun hasil dari validasi teman sejawat menyatakan bahwa soal-soal sesuai untuk mengevaluasi hasil belajar siswa dalam materi fotosintesis. 


\section{Analisis Data}

Teknik analisis data merupakan upaya mencari dan menata secara sistematis hasil dari observasi, tindakan dan dokumentasi untuk meningkatkan pemahaman penelitian terhadap kasus yang diteliti dan menyajikannya sebagai temuan bagi orang lain. Kegiatan analisis merupakan refleksi dari data sebelum tindakan dan hasil selama dan setelah tindakan.

Analisis data dalam penelitian ini disajikan dalam bentuk analisis kualitatif dengan metode pemaparan secara deskriptip komparatif, yakni mendeksripsikan semua temuan dalam penelitian disertai dengan data-data kuantitatif yang dianalisis secara sederhana

\section{Indikator Keberhasilan}

Indikator keberhasilan dalam penelitian ini dalam bentuk hasil belajar siswa khusus pada pemahaman terhadap fotosintesis pada tumbuhan. Adapun indikator keberhasilan tersebut adalah: (1) Perolehan nilai rata-rata minimal 70,00 (2) tingkat kelulusan KKM sedikitnya $75 \%$ atau 18 siswa.

\section{HASIL DAN PEMBAHASAN}

\section{Kondisi Awal Siswa}

Berdasarkan data dokumentasi hasil skor siswa kelas V SD Negeri Tlahap semester 1 tahun pelajaran 2018/2019 kurang termotivasi dalam pembelajaran IPA materi fotosintesis, terbukti dengan banyaknya siswa yang tidak memperhatikan penjelasan guru, siswa bercerita ketika kegiatan pembelajaran, dan siswa malas mengerjakan latihan. Kondisi tersebut karena dalam pembelajaran guru masih mendominasi dengan metode ceramah dan belum memanfaatkan media youtube dengan metode pembelajaran. Dari data nilai siswa yang diperoleh yang menunjukkan kondisi awal siswa sangat rendah. Siswa yang mencapai kriteria ketuntasan minimal (70) hanya ada 8 atau $(34,78 \%)$ dengan nilai rata-rata 57,52 masih 15 siswa atau (65.21\%) yang belum tuntas KKM, dari jumlah siswa seluruhnya 23. Dari data tersebut, perlu diadakan penelitian agar hasil belajar siswa dapat meningkat.

\section{Deskripsi Siklus 1 \\ Persiapan Tindakan}

Berdasarkan identifikasi permasalahan yang telah dideskripsikan, peneliti menyusun Rencana Pelaksanaan Pembelajaran (RPP) dengan mendesain program pembelajaran dengan langkah-langkah: 1) Menentukan standar kompetensi, 2) Menentukan kompetensi dasar, 3) Menentukan indikator, 4) Menentukan tujuan yang hendak dicapai, 5) Menentukan materi yang disesuaikan dengan tujuan yang akan dicapai, 6) Menyiapkan media youtube fotosintesis, 7) Menentukan metode yang akan digunakan untuk menyampaikan pembelajaran, dan 8) Menentukan alat evaluasi.

Setelah RPP disusun, maka kegiatan selanjutnya adalah menyiapkan media yang akan digunakan dalam penelitian yaitu media youtube fotosintesis yang tentunya sudah disiapkan semua perlengkapan, seperti modem, laptop, proyektor, speaker, serta perangkat pembelajaran lainnya seperti LKS dan instrumen penilaian.

\section{Pelaksanaan Tindakan}

Pada saat pelaksanaan tindakan di siklus 1 ini, peneliti melakukan tindakan diantaranya (a) mengidentifikasi kebutuhan siswa, (b) Seleksi pendahuluan terhadap prinsip-prinsip, pengertian, konsep dan generalisasi yang akan dipelajari, (c) Seleksi bahan, dan problema serta tugas-tugas, (d) Membantu memperjelas problema yang akan dipelajari dan peranan masing-masing siswa, (e) Mempersiapkan setting kelas dan alatalat yang diperlukan, (f) Mencek pemahaman siswa terhadap masalah yang akan dipecahkan dan tugas-tugas siswa, (g) Memberi kesempatan kepada siswa untuk 
melakukan penemuan, (h) Membantu siswa dengan informasi, data, jika diperlukan oleh siswa, (i) memimpin analisis sendiri dengan pertanyaan yang mengarahkan dan mengidentifikasi proses, (j) Merangsang terjadinya interaksi antar siswa dengan siswa, (k) memuji dan membesarkan siswa yang bergiat dalam proses penemuan, (l) Membantu siswa merumuskan prinsip-prinsip dan generalisasi atas hasil penemuannya.

\section{Pengamatan}

Kegiatan pembelajaran yang dilakukan pada siklus 1, pertemuan pertama membahas tentang arti fotosintesis, dan pertemuan kedua menjelaskan materi apa saja yang dibutuhkan dalam proses fotosintesis. Hasil pengamatan tentang motivasi belajar siswa dalam kegiatan pembelajaran IPA materi fotosintesis.

Data yang diperoleh dapat di deskripsikan bahwa selama kegiatan pembelajaran dengan memanfaatkan media youtube dengan meggunakan metode youtube ternyata: siswa berperan aktif dalam pembelajaran, siswa tertarik menggunakan media pembelajaran, motivasi siswa terhadap pembelajaran IPA meningkat, siswa aktif dalam berdiskusi, siswa lebih cepat dalam mengerjakan tugas agar dapat segera mencocokkan hasilnya dengan laptop, dan siswa semakin semangat mengerjakan soal yang menyebabkan hasil belajar meningkat dibandingkan dengan dengan sebelumnya.

\section{Refleksi}

Hasil pembelajaran dengan memanfaatkan media youtube dan metode pembelajaran yang digunakan menggunakan metode discovery ini, dapat dikemukakan beberapa kekurangan yang dapat digunakan sebagai acuan untuk kegiatan siklus berikutnya. Kelemahan pada siklus pertama antara lain: 1) Siswa masih sering ragu ketika ingin mengungkapkan pendapatnya, 2) siswa masih bingung dalam diskusi dengan kelompoknya, 3) ketika mengerjakan lembar kerja masih ada siswa yang kurang konsentrasi, itu dikarenakan pembagian kelompok yang kurang merata, dan masih bersifat homogen.

Akan tetapi dalam siklus 1 ini Ada peningkatan hasil belajar siswa, yaitu dari ratarata 57,52 menjadi 66,52, ini berarti ada peningkatan sebesar 9,00 (Sembilan koma nol). Siswa yang tuntas KKM juga ada peningkatan, yaitu yang semula hanya ada 8 atau $(34,78 \%)$ meningkat menjadi 15 siswa atau $(65,21 \%)$. Hal ini karena pembelajaran IPA pada materi fotosintesis dilakukan dengan memanfaatkan media youtube dan metode discovery. Pembelajaran ini masih perlu ditingkatkan karena indikator kinerja belum tercapai, yakni rata-rata kelas harus 70 dan tingkat pencapaian KKM belum mencapai 91,30\% atau 21 siswa. Hasil dari refleksi pembelajaran pada siklus pertama ini dipergunakan sebagai pedoman dalam penyusunan persiapan pelaksanaan pembelajaran untuk siklus yang ke dua.

\section{Deskripsi Siklus 2}

\section{Persiapan Tindakan}

Berdasarkan refleksi yang telah dideskripsikan serta analisis hasil belajar pada siklus 1, disusun Rencana Pelaksanaan Pembelajaran untuk dua kali pertemuan dengan langkah seperti siklus 1, dengan materi dan teknik yang kurang dalam siklus 1 disempurnakan, yaitu fokus pada pembagian kelompok yang heterogen. Materi pada pertemuan pertama adalah menjelaskan bahan apasaja yang dibutuhkan dalam proses fotosintesis, pertemuan kedua menjelaskan hasil dari fotosintesis. Media yang digunakan tetap yakni media youtube dan metode discovery, sehingga guru tidak perlu membuat media lagi, hanya saja langkah pembelajarannya lebih diefektifkan.

\section{Pelaksanaan Tindakan}

Langkah-langkah pembelajaran pada siklus 2 ini adalah: 1) Guru menjelaskan kegiatan yang akan dilakukan, 2) Guru menyiapkan media yang dibutuhkan, 3) siswa 
dibagi menjadi beberapa kelompok secara heterogen 4) siswa memperhatikan video youtube yang telah ditayangkan oleh guru, 5) siswa mengamati bersama kelompoknya, 6) setiap kelompok berdiskusi tentang faktor yang diperlukan dalam proses fotosintesis berikut dengan hasil fotosintesis, 7) Setelah semua kelompok selesai berdiskusi, perwakilan kelompok untuk mempresentasikan hasil diskusinya di depan kelas, yang selanjutnya ditanggapi oleh kelompok lain dan diberi penguatan oleh guru.

\section{Pengamatan}

Berdasarkan hasil pengamatan dapat dikatakan bahwa peran aktif siswa dalam pembelajaran fotosintesis telah meningkat, motivasi siswa dalam pembelajaran IPA juga semakin baik, antusias siswa dalam mengerjakan latihan meningkat, semangat mengerjakan tugas meningkat dan hasil belajar siswa meningkat tajam.

\section{Refleksi}

Kegiatan pembelajaran pada siklus 2 menurut masukan dari teman sejawat dan berdasarkan analisis dari peneliti sudah berjalan dengan optimal. Kekurangan dari pembelajaran ini adalah masih ada 1 siswa yang belum tuntas. Namun 1 siswa tersebut perlu mendapat bantuan bimbingan berlajar secara khusus dari teman anggota kelompoknya atau dari guru, karena siswa tersebut termasuk siswa yang IQnya di bawah rata-rata, dan tergolong siswa berkebutuhan khusus ditambah matanya sudah minus 4 .

Adapun kelebihannya adalah prestasi belajar siswa meningkat tajam dari rata-rata kelas 66,52 menjadi 80,00 sehingga ada peningkatan sebesar 13,48. siswa yang mencapai KKM yang di siklus 1 ada 15 siswa atau $(65,21 \%)$ menjadi 22 siswa atau 95,65\% siswa lebih tertarik dalam belajar menggunakan media youtube, dan lebih semangat dalam berdiskusi dengan temannya, dan pada siklus 2 ini siswa dapat menyelesaikan latihan serta tes formatif dengan waktu yang lebih cepat dari pada siklus 1 . Karena indikator keberhasilan sudah terpenuhi, maka penelitian ini sudah terbukti, dan tidak perlu dilanjutkan ke siklus berikutnya.

\section{Pembahasan Hasil Penelitian}

Dengan pemanfaatan media youtube dan metode pembelajaran menggunakan metode discovery ternyata dapat menarik perhatian dan motivasi belajar lebih meningkat. Siswa yang biasanya perhatiannya kurang, tampak menjadi lebih antusias pada pembelajaran ini. Demikian pula siswa yang sudah mulai jenuh dengan pembelajaran yang monoton dan tidak bervariasi, kembali lebih berkonsentrasi dan motivasi belajar siswa meningkat dalam pembelajaran fotosisntesis. Hal ini senada dengan manfaat dari penggunaan media pembelajaran ini, menurut Hamalik (1994 : 108) antara lain adalah : 1) menarik minat, 2) memberi gambaran yang jelas, 3) mempunyai tinjauan yang luas dan 4) mendorong kreativitas siswa .

Berkaitan dengan pendapat tersebut, maka pemanfaatan media youtube dan metode discovery memang dapat menarik minat siswa untuk belajar dan memahami konsep fotosintesis pada tumbuhan, sehingga siswa mempunyai tinjauan yang luas dalam menyelesaikan masalah mulai dari permasalahan yang mudah dan sederhana hingga yang kompleks (Sartono, Rusdi, \& Handayani, 2017). Hasil belajar siswa dengan menggunakan media youtube dan metode discovery lebih tinggi dari pembelajaran sebelumnya, terbukti dengan nilai yang diperoleh siswa setelah tindakan diberikan dalam ulangan yakni: pada pra siklus dengan nilai rata-rata 57,52, pada siklus 1 dengan ratarata 66,52, dan pada siklus 2 dengan rata-rata 80,00. Siswa yang telah tuntas KKM juga meningkat dengan signifikan, yaitu semula hanya ada 8 atau $(34,78 \%)$ meningkat menjadi 15 siswa atau $(65,21 \%)$ pada siklus 1 dan menjadi 22 siswa atau 95,65\% pada siklus 2 .

Jika disajikan dalam bentuk grafik akan terlihat seperti gambar berikut ini. 


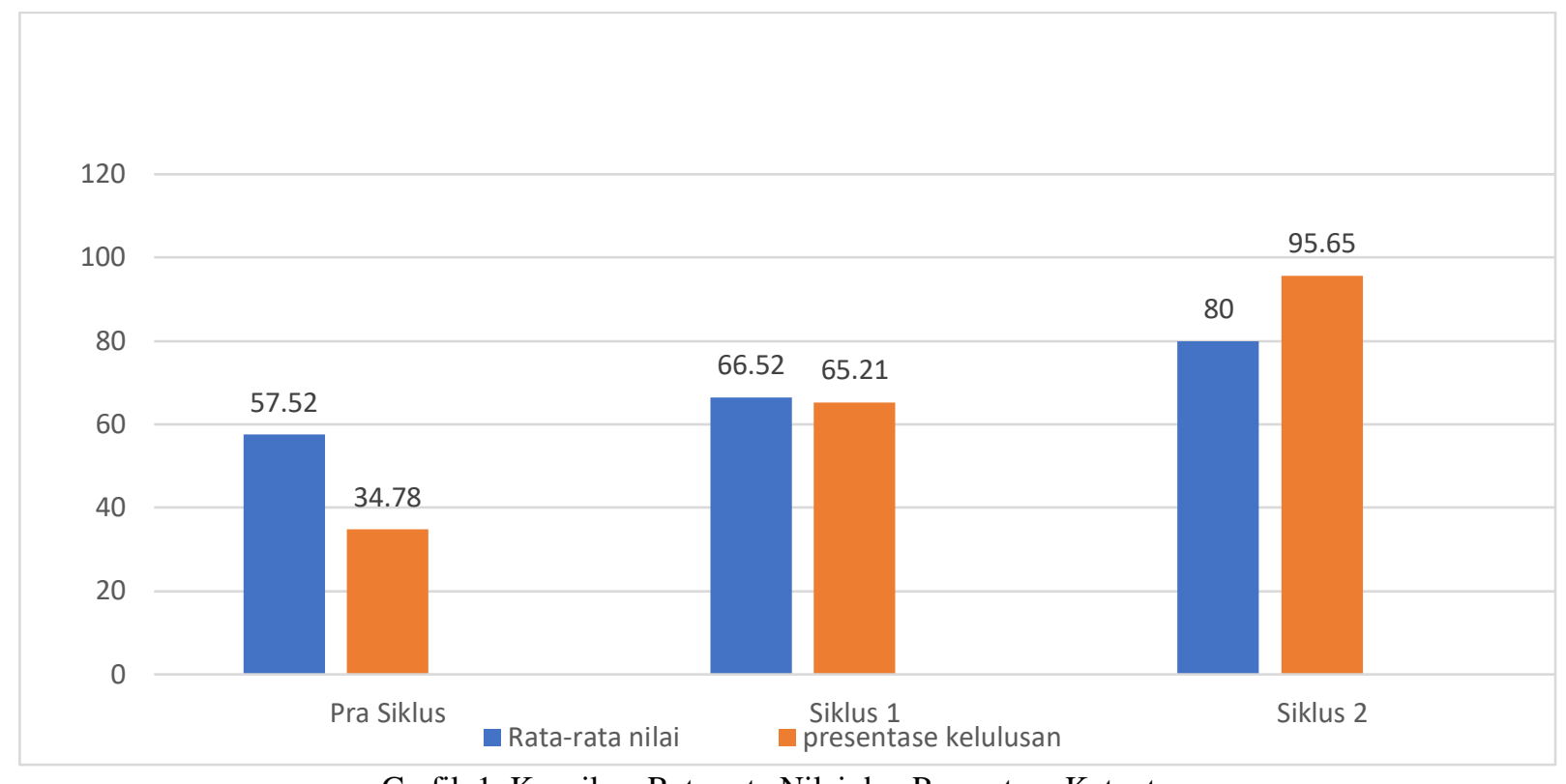

Grafik 1. Kenaikan Rata-rata Nilai dan Prosentase Ketuntasan

Dari grafik di atas, dapat ketahui dari penelitian yang dilaksanakan 2 siklus, ada peningkatan yang cukup signifikan pada setiap siklusnya

\section{KESIMPULAN \\ Simpulan}

Penggunaan media pembelajaran youtube dan metode discovery dalam materi fotosintesis lebih efektif untuk meningkatkan motivasi belajar siswa dalam pembelajaran IPA materi fotosintesis di kelas V SD Negeri Tlahap semester 1 tahun pelajaran 2018/2019.

Hasil belajar siswa dengan menggunakan media youtube dan metode discovery lebih tinggi dari pembelajaran sebelumnya, terbukti dengan nilai yang diperoleh siswa setelah tindakan diberikan dalam ulangan yakni: pada pra siklus dengan nilai rata-rata 57,52, pada siklus 1 dengan rata-rata 66,52, dan pada siklus 2 dengan rata-rata 80,00. Siswa yang telah tuntas KKM juga meningkat dengan signifikan, yaitu semula hanya ada 8 atau $(34,78 \%)$ meningkat menjadi 15 siswa atau $(65,21 \%)$ pada siklus 1 dan menjadi 22 siswa atau $95,65 \%$ pada siklus 2 .

\section{Saran}

Untuk mengintensifkan pemanfaatan media youtube dan metode discovery dalam pembelajaran IPA, dapat disarankan sebagai berikut: Kepada Kepala Sekolah supaya lebih banyak memberikan motivasi kepada guru dalam kegiatan belajar dan mengajar agar memanfaatkan media yang bervariasi, kepada Guru supaya meningkatkan kemampuannya dalam kegiatan pembelajaran dan mengembangkan kreativitas dalam pembelajaran di antaranya dengan memanfaatkan media youtube, serta pihak sekolah sebagai penyelenggara pendidikan hendaknya melengakapi fasilitas dan kebutuhan siswa dalam kegiatan belajar dan mengajar.

\section{DAFTAR PUSTAKA}

Arikunto. 2007. Penelitian Tindakan Kelas. Jakarta: Bumi Aksara.

Bahtiar, B., \& Dukomalamo, N. (2019). Basic science process skills of biology laboratory practice: improving through discovery learning. Biosfer: Jurnal Pendidikan Biologi, 12(1), 83-93. 
Budiani, Ni Wayan. 2009. Efektifitas Program Penanggulangan Pengangguran Karang Taruna "Eka Taruna Bhakti" Desa Sumerta Kelod Kecamatan Denpasar Timur Kota Denpasar. Input, vol. 2 (1) : 49-57

Bungkaes H.R, J. H. Posumah, Burhanuddin Kiyai. 2013. Hubungan Efektifitas Pengelolaan Program Raskin dengan Peningkatan Kesejahteraan Masyarakat di Desa Mamahan Kecamatan Gemeh Kabupaten Kepualauan Talaud. Acta Diurna, vol. - (-) : 1-23

Burnett, Melissa (2008) Integrating Interactive Media Into The Classroom: Youtube Raises The Bar On Student Performance diakses dari http://search.proquest.com/docview/192409999/13A21CCBDC634AB366A L4? accountid $=17242$

Campbell. 2002. Biologi Jilid 1. Jakarta : Erlangga

Djamarah, 2006. Strategi Belajar Mengajar. Jakarta : PT Rineka Cipta

Gie 1980. “Dasar-Dasar Administrasi, Suatu Kumpulan Karangan Di Daerah” Jakarta : Pradnya Paramita

Herdian. 2010. Kemampuan pemahaman matematika : Bandung

Hosnan, M. 2014. Pendekatan Saintifik dan Kontekstual dalam Pembelajaran Abad 21. Bogor: Ghalia Indonesia.

Kimball, 1998. Biologi Jilid 1. Jakarta : Erlangga.

Kurniasih,dkk. 2014. Implementasi Kurikulum 2013 Konsep dan Penerapan. Surabaya: Kata Pena.

Sartono, N., Rusdi, R., \& Handayani, R. (2017). Pengaruh pembelajaran process oriented guided inquiry learning (pogil) dan discovery learning terhadap kemampuan berpikir analisis siswa sman 27 jakarta pada materi sistem imun. Biosfer: Jurnal Pendidikan Biologi, 10(1), 58-64.

Simamora, Raymon (2009). Pendidikan dalam keperawatan Jakarta : EGC

Simanjutak. 1983. Metodologi Pendidikan. Bandung. Citra Adi Karya.

Sudjana. 2001. Metode \& Teknik Pembelajaran Partisipatif. Bandung : Falah Production.

Sudjana, 1992. Media Pengajaran. Bandung: Sinar Baru.

Suherman, dkk. (2001). Common TexBook Strategi Pembelajaran Matematika Kontemporer. Bandung: Jurusan Pendidikan Matematika UPI Bandung.

Suryabrata, 1998. Psikologi Pendidikan. Jakarta: PT. Raja Grafindo Persada.

Sutrisno. 1997. Metode Penelitan. Yogyakarta: Andi Ofset.

Sutrisno, 2000. Statistik Jilid 2, Yogyakarta: Andi Offset.

Tim MKDK IKIP Semarang. 1996. Belajar dan pembelajaran. Semarang: IKIP press.

Toy, B. A., Karwur, F. F., da Costa, J. F., Langkun, J. F., \& Rondonuwu, F. S. (2018). Design of biology teaching materials based on discovery learning with scientific approach for class 10th in senior high school. Biosfer: Jurnal Pendidikan Biologi, $11(1), 68-77$. 